\title{
Implementation of Human Capital Management in HR Section of the Hang Tuah School of Health Science (STIKES) Pekanbaru
}

\author{
Ennimay \\ Doctoral Program, Human Resource Management, Jakarta State University \\ Jl. Rawamangun Muka, RT.11/RW.14, Rawamangun, \\ Jakarta Timur, 13220, Indonesia \\ Tel: +62-821-7513-653 \\ Email: Ennimay@yahoo.com \\ Hady Efendy (Corresponding Author) \\ Education Practice and Academic Consultant, Indonesia \\ Tel: +62-852-8900-7870 \\ E-mail: efendy_hady@yahoo.co.id
}

Received: Oct. 12, 2017 Accepted: Oct. 28, $2017 \quad$ Online published: Nov. 1, 2017

doi:10.5296/ijhrs.v8i1.11984ＵRL: https://doi.org/10.5296/ijhrs.v8i1.11984

\begin{abstract}
To manage people to stay ahead and be able to manage the changes of civilization in need of new ways. There is a paradigm shift in view of human positions within the organization. Man is a factor of production, man is the main driver of production and man is an organizational strategic asset. Problem Formulation: How Human Capital Management Implementation in Human Resources Department of Hang Tuah School of Health Science. Purpose of Writing: To analyze the implementation of Human Capital Management in Human Resource of Hang Tuah School of Health Science. Writing method used is descriptive analysis with case study approach. Conclusion: There is still a poor understanding of the Human Resources Manager of Human Capital as an organizational asset. According to the authors need reinforcement on the HR of Hang Tuah School of Health Science, so that all strategies and policies that have been set by the leadership can be done properly and correctly. In order for the HR Section to
\end{abstract}


apply the Working Model of Excellent by integrating the managerial process and business results achieved. Need to understand and change the paradigm of the HR Manager that more and more companies are interested in using invisible assets and human capital as a way to gain more profit from competitors.

Keywords: human capital, human capital management, intangible assets, working model of eccentrics (MKE)

\section{Introduction}

Manage people to stay ahead and be able to manage the changes of civilization in need of new ways. There is a paradigm shift in view of human positions within the organization. Man is a factor of production, man is the main driver of production and man is an organizational strategic asset. The basic principle of human resource management is the suitability between work and people.

Table 1. The Shifting Theory and Practice of Human Resource Management (HR)

\begin{tabular}{|c|c|c|}
\hline $\begin{array}{l}\text { Personnel Management or } \\
\text { Personnel } \\
\text {... Late 1970s. }\end{array}$ & $\begin{array}{lr}\text { Human } & \text { Resource } \\
\text { Development } & \text { (HRD) } \\
\text { Management } & \\
\text { 1980s - Mid 1990s. } & \\
\end{array}$ & $\begin{array}{l}\text { Human Capital Management } \\
\text { Middle of the 1990s - now. }\end{array}$ \\
\hline $\begin{array}{l}\text { Focus on the administrative } \\
\text { aspects of personnel } \\
\text { management. }\end{array}$ & $\begin{array}{l}\text { Human is not just a factor of } \\
\text { production, but must be } \\
\text { developed and humanized. }\end{array}$ & $\begin{array}{l}\text { Human is an organizational } \\
\text { strategic asset, therefore it } \\
\text { must be managed specifically } \\
\text { as a strategic asset. }\end{array}$ \\
\hline
\end{tabular}

Since the mid-1990s until now there has been a shift in the role of HR Management from Old Model to New Model is as follows:

Old Model

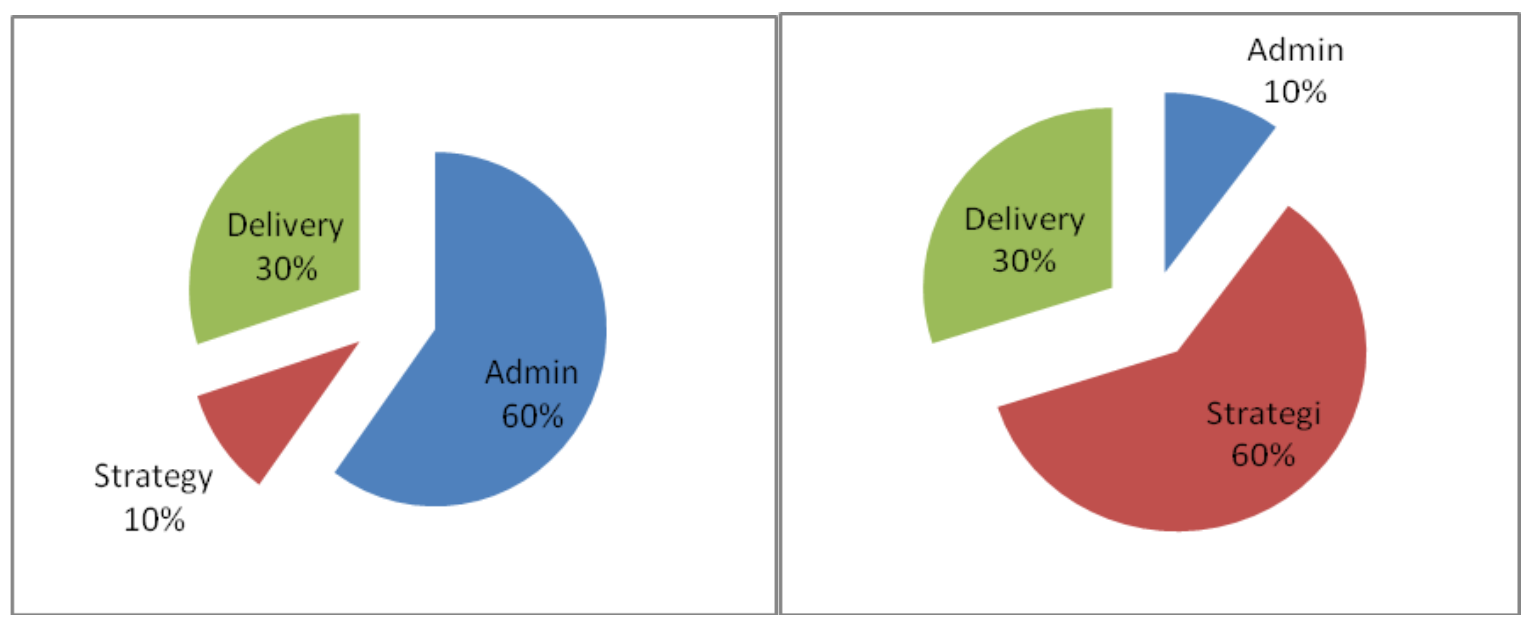

Figure 1. Shifting Role of HR Management

Technology makes administrative and clerical processes can be replaced by an information system. 


\section{Macrothink}

International Journal of Human Resource Studies

ISSN 2162-3058

2018, Vol. 8, No. 1

Stake

Holder

Customer

Internal
Process

Learn And

Growth



Figure 2. Human Capital and Map of Strategic

Competition between companies in the era of globalization increasingly sharp, so that human resources (HR) is required to continuously develop themselves proactively. HR should be the human-learner of individuals who want to learn and work hard with full of spirit, so that the potential of human beings to grow maximum. HR is needed today is the human resources capable of mastering technology quickly, adaptive, and responsive to technological changes. In this condition personal integrity is increasingly important to win the competition.

In order for the company to continue to survive and compete, must be supported by reliable human resources, technology dominance is not enough, so investment in the most valuable economic resources, namely HR cannot be postponed again. Basically, human resources are a resource that the organization desperately needs. Therefore, human resources is a source that plays an active role in the way an organization and decision-making process.

Therefore, The Hang Tuah School of Health Science as a public organization need to build an adaptive culture of change, have strong commitment and have sufficient competent human capital to capture the objectives of Human Capital Management (HCM). To fulfill the task of making a paper about human capital management the author tries to perform an analysis of the implementation of Human Capital Management at Hang Tuah School of Health Science. According to the authors of the problems facing the HR section of Hang Tuah School of Health Science is the gap between the existing forces with the demands of the job.

\section{Methodology}

The writing method used in this paper is descriptive analysis with case study approach. Research is based on data available in books, literature and media. Then evaluate how Human Capital Management Implementation in Human Resources Department of Hang Tuah School 
of Health Science, which covers the essence of evaluation, what will be evaluated, and how evaluation is done. The focus of this research is Implementation of Human Capital Management in Human Resources Department of Hang Tuah School of Health Science with the aim to analyze the implementation of Human Capital Management in Human Resources of the Hang Tuah School of Health Science.

\section{Literature Review}

\subsection{Concept of Human Capital}

\subsubsection{Understanding Human Capital}

Literally the definition of human capital is the knowledge, skills, abilities and skills that make human (employee) as capital or asset of a company. The company treats employees as capital then the company will gain greater benefits than just treating employees as a resource (human resource). By considering employees as capital possessing knowledge, expertise, and skills based on this matter, people working in a company can run other resources.

Bontis et al (1999: 393) defines; Human Capital represents the human factor within the organization; a combination of intelligence, skill and expertise that gives the organization a distinctive character. The human elements of the organization that have the ability to learn, change, innovate and provide the creative impetus which, if appropriate motivate, can ensure long-term survival of the organization.

While Scarborough \& Elias (2002) commented that: "The concept of human capital is the most useful view as a bridging concept-that is, human capital is defined as the link between human resource practices and business performance in terms of assets / assets on business processes'. (Armstrong's Handbook of Human Resource Management Practice Michael Armstrong Ed-12 London: Kogan Page, 2012).

Human capital is the accumulation of knowledge, expertise, and other relevant workforce attributes within the organizational strength of an organization and spur the productivity, performance and achievement of strategic objectives. If a company considers an employee as a resource, when a human (employee) who works in a company is no longer productive, then the company can simply fire or lay off the employee. The employee's knowledge, skills, and skills that are discontinued are not used anymore. While people (employees) are not working, the company can still use the knowledge, skills, and skills of employees who have not worked within a particular company.

\subsubsection{Human Capital as a Visible Asset (Tangible Asset)}

Human Resources as a strategic central factor in the form to run the various interests of the company vision. There has been a change of view on the world environment at this time about various resources that are strategic for the company. The change is from the dominance of physical resources (tangible assets) towards intangible assets.

The view that knowledge as a strategic corporate resource is based on the fact that knowledge can be used to develop competitiveness of companies of value, scarce, difficult to imitate by 
competitors and irreplaceable by other types of resources. So with the existing knowledge of the organization or knowledge through human labor that is in it, then humans are made visible capital (human capital).

According Mayo (2000), human capital has five components, namely:

a. Individual ability,

b. Individual motivation,

c. Leadership,

d. Organizational mood, and

e. Work group effectiveness.

Human beings as a tangible corporate asset, in addition to building, machinery, and money, are the drivers of resources, whether intangible (machinery, money, material or material) and intangible (information or data) (Mayo, 2012).

\subsubsection{Human Capital as Invisible Asset (Intangible Asset)}

An invisible asset is an asset that is different from a visible asset. However, it has the same interests. Examples of intangible assets can be seen as in product introduction, brand recognition, innovation, knowledge, capital, human resources and so on. According to Raymonnd A. Noe, John R. Hollenbeck, Barry Gerhart, Patrick Wright (2008) stated that, now more and more companies are interested in using invisible assets and human capital as a way to profit more from competitors. Included in a company's value are three types of important assets for a company to provide goods and services, i.e. financial assets (cash and stock), physical assets (buildings, factories, equipment), and invisible assets. Unseen assets are a kind of company asset including human capital, consumer capital, social capital, and intellectual capital.

The requirement of a company to have outstanding and sustained business performance continuously to sharpen the competitive edge of long-term and superior business performance desperately needs flexibility, innovation, and speed (especially from human resources and internal organizational capability) to enter the market. Competitive advantage as the key of human capital. The HR division is in a prime position to boost many other intangible assets, such as goodwill, research and advertising.

\subsection{Concept of Human Capital Management (Human Capital Management).}

\subsubsection{Understanding Human Capital Management}

HCM is sometimes defined more broadly without any emphasis on measurement. Chatzkel (2004) states that: 'Human Capital Management is an integrated effort to manage and develop human capabilities to achieve significantly higher levels of performance'. Dan Kearns (2005) describes HCM as: 'the development of human potential is totally declared as an organizational value'. He believes that 'HCM is about creating value through people' and this is 'a philosophy of human development that means something translated into value'. 
The purpose of HCM:

The four basic goals of HCM are to:

1. Determine the impact of people on the business and their contribution to shareholder value;

2. Demonstrate that human resource practices procedures are worth money, for example, return on investment (ROI);

3. Provide guidance for the future of human resources and business strategies.

4. Provide diagnoses and predictive data that will inform strategies and design practices to improve the effectiveness of people management within the organization. (Baron \& Armtrong, 2007)

Kearns (2006) argues that Human capital management has been described as a 'paradigm shift' from a traditional approach to human resource management-a great recognition.

Nalbantian et al (2004) emphasized aspects of human capital management measures. They define human capital as inventory of the accumulated knowledge, skills, experience, creativity and other relevant job promoting attributes and suggests that human capital management matrices to measure attribute values and use that knowledge to streamline organizational management.

Kearns (2005) defines human capital management as the total development of human potency expressed as the value of the organization. Kearns believes that human capital management is about creating value through people and in that it is a philosophy of human development, but that development means everything if interpreted into value.

\subsubsection{Human Capital Management and Human Resource Management}

All managers, especially line managers, should view human resources as one of their important job responsibilities. Unfortunately many managers are not looking at HR or his subordinates as a factor of company performance success. Currently there are still many managers who assume that their subordinates should be used as much as possible or exploited his energy without considering the human aspect.

If a company focuses its strategy on creating sustainable competitive advantage, the focus of the company's human resources is to maximize the contribution of human resources to the same goal, creating value for shareholders. The foundation or foundation for a strategy for the creation of human resource values is a management infrastructure that understands and is capable of implementing company strategy.

HR managers are limited in their ability to translate the company's operational strategies and objectives into the HR objectives that can be followed up, and further implement the objectives to be achieved. The ability of these managers to embed human resources into a larger strategy implementation system, which then produces a very important influence for the financial performance of the company. The competencies that HR managers need to 
develop as well as those that have the greatest impact on company performance are business competencies and strategic HR competencies. However, individual managers must be actively involved.

The role of HR personnel is to assist the operations of managers in developing their individual plans and integrate these different plans into an overall scheme. The strategic influence of HR focuses on the productive behavior of the people within the company. Integrating the focus on corporate performance behavior is a challenge in itself. The HR manager acts as a consultant to line managers on the understanding of people's management of business goals and strategies. The reverse line manager has a responsibility to respond to business intentions on business goals and strategies.

The point of the difference between human capital management and human resource management in the opinion of Mayo (2001) is the first to regard human beings as assets but the second treats them as costs (the former treats people as their latter treats as costs).

Kearns (2005) believes that in human capital management people or human beings are value adders, not additional costs, while human resource management is treated as a significant cost and must be managed accordingly. According to Kearns, in human capital management the human resources team is seen as a support service to the human-resource line based on the function and performance of the human resources team "a different and separate role from other functions". Conversely human capital management is clearly visible and valued as a balanced colleague at the senior level. And is a holistic, broad and system-based organization that becomes strategic and associated with added value.

How to strengthen the concept of human capital management or add the concept of resource management to the concept of human resource management are as follows:

a. Human capital management draws attention to the interest that Kearns says is "management by size", aimed at forming a clear presence between human resource intervention and organizational success;

b. Strengthen the belief in human resources that human beings are assets rather than costs;

c. Focusing attention to needs based on human resource management strategies and processes in terms of creating value through people and thus the subsequent achievement of organizational goals;

d. Emphasize the need to be strategic;

e. Emphasizes the role of human resources specialists as business partners;

f. Provide guidance on what is measured and how to measure;

g. Underline the importance of using measures to prove that superior human management produces superior results and to indicate which direction the strategy should proceed.

\subsection{Components of the Human Capital Strategy}

HCS Component 1: The Executive Team is effective. Is your executive team better this year 


\section{Macrothink}

than last year? What's "better"?

HCS Component 2: Leaders Who Deliver Results. Is your leader better this year than last year? Think of the financial investment that goes into building a competent leader.

HCS Component 3: Key Position Excellence. A key position is defined as an important non-management role that requires a higher level of investment than any other role. Examples of key positions can be found by looking at IBM. At IBM, major dealers have no direct reports but can sell outsourcing multiyear of $\$ 1$ billion.

HCS Component 4: Workforce Performance. Many executives do a lot of ways to be able to ensure high-performing organizations, but how many can do it? Most executives turn to appraisal and reward systems to drive performance improvements.

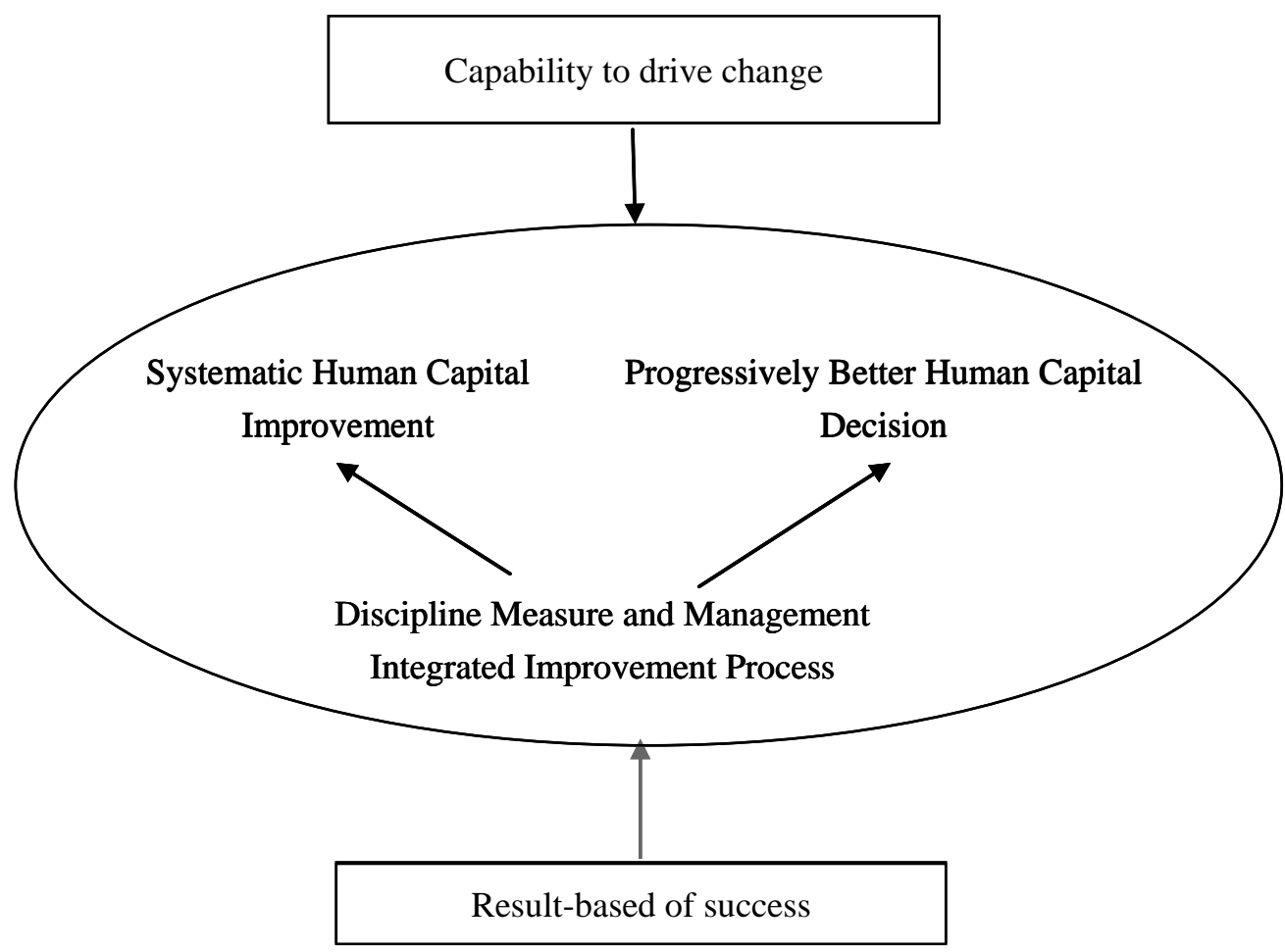

Figure 3. The Performance Improvement Roadmap

The Outcomes of HCS are:

Outcome 1: Increased Human Capital System

The first expected result of the Human Capital Strategy is knowing whether the system is improving performance or not. This does not just answer the question.

Outcome 2: Better progressive decisions of Human Capital

Do leaders throughout your organization make better human capital decisions this year than they did last year? Does your organization learn through experience? (Hall, 2008) 


\subsection{Human Resource Strategy}

\subsubsection{HRM Strategy}

The HRM strategy is an approach that defines how organizational goals will be achieved through the organization by defining human resource strategies and integrated with human resource policies and practices. This is defined by Mabey, et al (1998: 25) as a process of, 'Development of a firm's ability to generate new organizational strategies. (Armstrong, 2012)

Strategic management can be defined as art and knowledge in formulating, implementing, and evaluating cross-functional decisions that enable an organization to achieve its goals. In essence, a strategic plan is a company's game tactics. Just as a soccer team needs good tactics to win, a company must have a good strategic plan to compete successfully. (David, 2012)

Understanding Human resource strategy management is to formulate and execute the policies and practices that produce the competencies and employee behavior that the company needs to achieve its strategic objectives. For example, when Yahoo CEO wanted to improve his company's innovation and productivity a few years ago, he chose a new human resources manager. Yahoo then makes a lot of new policy-policy human resources. (Desseler, 2016)

The human resource strategy relates to the mission, vision, corporate strategy, SBU (Strategy Business Unit), as well as functional strategy. Determination of human resource strategy needs to consider and consider the mission, vision, and corporate strategy, and need to be formulated logically, clearly, and applicable. Human resource strategies support the implementation of corporate strategy and need to be translated into HR activities, policies, programs that align with corporate strategy will influence the achievement of corporate objectives.

Human Resource Strategy relates, among others, to the establishment of an appropriate corporate culture, human resource planning, auditing human resources both qualitatively and quantitatively, as well as human resource activities such as human resource procurement (from recruitment to selection), orientation, maintenance, training and human resources development, HR, external factors need to be considered referring to future needs and trends, supply and demand, government regulations, human needs in general and employees in particular, potential competitors, social changes, demographics, culture and values, technology. The trend of environmental change will affect changes in corporate strategy which also means that the HR strategy also needs to be reconsidered, and most likely needs to be adjusted. The change of HR strategy is not something taboo but needs to be done with careful consideration.

Companies must choose the right business strategy in order to be able to take advantage of business opportunities and anticipate the constraints that occur as the impact of rapid environmental change. One of the most important keys to achieving competitive advantage is through the effective management of human resource strategies. Development and implementation of human resource strategies reflected in HR activities, such as procurement, maintenance and development must be in line with the business strategy and corporate culture. Partnership with other companies is a characteristic to increase the productivity and achievement of the company. Therefore, the network structure and corporate culture that 
refers to innovation, creativity, and continuous learning is the right choice for companies that want to survive and develop (Sutrisno, 2016).

\subsubsection{New Human Capital Strategy}

Does your company have a strategy to improve its human resources? Maybe that's in the whole HR strategy. If so, then we need to see if the current HR strategy is sufficient to improve business performance through our Human Capital, here are some questions that each organization needs to answer whether he has utilized Human Capital (HC) appropriately or not:

a. Does the business strategy describe the capabilities of the people and organizations that are most important to delivering every goal? Is this capability reflected in the HR strategy?

b. Is the HR strategy a top-down spoil of business strategy, or is it a project undertaken by the HR sub-profession (i.e. staffing, compensation, and training)?

c. What percentage of the value of HR metrics directly matches the strategic objectives of the business? Which metrics are important to external customers?

d. How certain are you that you're current HR strategy will significantly increase customer and shareholder satisfaction?

\subsubsection{Building a Human Capital Blueprint (HC)}

Assist the organization in drafting the Human Capital Management strategic plan to align with the organization's strategic plan, including developing the steps of strategy and activities that need to be done. With the HCM Blueprint the organization can have an HCM strategic plan that supports the company's strategic plan and the availability of the stages of activities that are the source of annual planning.

The following are the components of the human capital blueprint building:

1. Human Capital Strategy: The plan how people create business value.

2. Human Capital Theory: A description of the causes of how people create business value.

3. Vision of Human Capital: A blueprint can be said to be successful; what a sustainable competitive advantage through such people completes. Also called the end goal of the organization.

4. Strategic Components: The most important result to realize the vision of Human Capital.

Here are the theories that help to find out the human capital in a person's organization:

1. Ask HR why they chose a particular decision. Continue to ask repeatedly to what extent the utilization of human resources in an organization.

2. Look at the organizational performance goals, each department of the organization, and each individual within the organization.

3. Look at whose being promoted. What makes them stand out?

4. Which is the most powerful HR department? 


\section{Macrothink}

International Journal of Human Resource Studies ISSN 2162-3058 2018, Vol. 8, No. 1

5. How does the Chief Human Resources Officer utilize operational time in the work environment?

6. Ask a HR professional, "What is the most important asset in the organization?

7. Run an activity analysis on HR generalists.

The vision of human capital is founded on the theory of human capital and the attempt to turn theory into a concrete statement. Here is to set the Vision of Human Capital into a concrete statement:

1. The main steps are defined by performance, not competence. Competence is an important means to end and must be measured and managed as such; but success is the best performance industry, not the industry's best people.

2. Success is measured against industry benchmarks or primary competitors. Being a world class is ideal, but it is not required to deliver business results.

3. Often, but not always, it is possible to compare the performance of non-management roles with similar roles in competing firms (e.g., sales, customer service).

4. If the competitor's performance cannot be scored, measure changes from year to year note that performance metrics will not be perfect.

The Strategic Components of Human Capital, as follows:

1. Effective Executive Team: The executive team must continually improve the value they produce for the wider organization.

2. Leaders who deliver results: Leaders must align all activities to achieve business plans and improve organizational capabilities that enable high performance.

3. Outstanding key positions: The most important non-management positions for customers and shareholders should be able to deliver better performance than their counterparts in a competing organization.

4. Labor Performance: Organizations must have the structure, system, and culture to enable great performance. Good performance means higher productivity and better cost structure than competitors.

3.4.4 To Create of Performance to Blueprint Execute

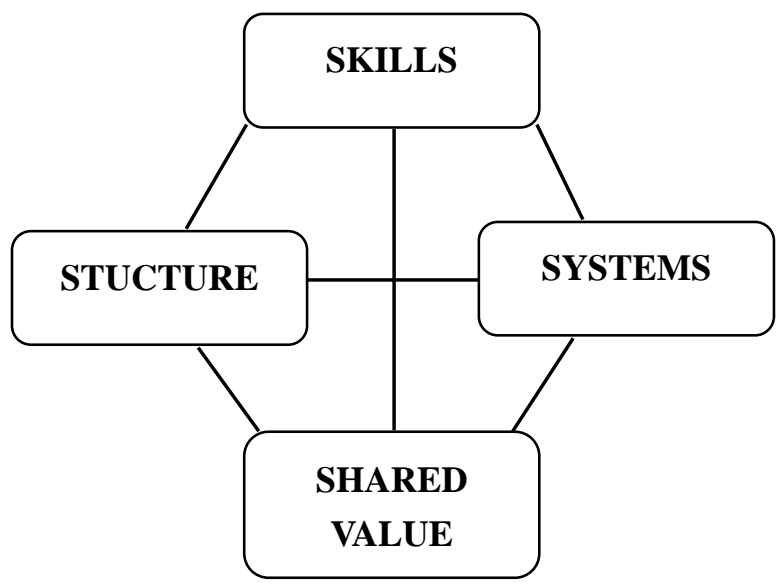

Figure 4. Current Human Resource Function 
These functions are:

1. Structure i.e., who reports to whom, role, and accountability,

2. System (i.e., performance measures, business reviews),

3. Shared values (i.e., beliefs, cultural values),

4. Skills / skills (i.e., talent, knowledge). The elements are parallel to each other. (Hall, 2008)

\subsection{Strategies and Road Map Human Capital Development}

It is time we get human capital as a strategic issue in the overall planning of the company. it is almost inconceivable that suddenly we have to deal with competitors who have financial strength but at the same time using the power of economic knowledge.

A good example is Singapore, although the country is successful in regenerating starting from a serious investment in the field of human capital. It is evident that Singapore currently lives from the service sector, even starting to sell its education and training services. Among its citizens too, many have become expatriates working in foreign countries.

SOEs indeed control quite a lot of human capital potentially even the number of educated master and doctor grew. However, human capital as part of the economic knowledge is a force that must be built continuously as the change continues. Moreover, this power does not just come and need to be built based on a development road map that every step should be taken seriously. Therefore, the synergy between SOEs and networking with external parties becomes very important to continue to explore the national talent that selling power and high competitiveness.

\subsubsection{Performance Model of Human Capital Excellent / Human Capital Indonesia}

Performance Model Excellent (MKE) is a model used as a guide to achieve excellent performance. There are many references to MKE, such as the Malcolm Bridge Criteria for Performance Excellence (MBCFPE), the European Quality Award, or the Australian Business Excellence Award. In this paper, the main reference is MBCFPE, as used in many countries in Europe and Asia Pacific. MKE does not specifically require the use of certain management tools to achieve exemplary performance, but rather focus on implementing effective management tools. Unlike other management systems, MKE integrates managerial processes and business results achieved.

Exemplary performance model consists of five categories:

1. Leadership;

2. Strategic planning;

3. Focus on customers and markets;

4. Process management; and

5. Business results

The main purpose of the compilation of performance model is to help each company to improve its performance, both process performance and yield performance. 
MKE has an important role:

1. Assisting companies in improving the performance, capability and results of operations.

2. Being a communication and sharing media for the best performance among work units / companies.

3. Guiding the company in managing performance, planning, and learning process.

The main characteristics of MKE are:

1. Focus on results (products and services, customers, finance and markets, human capital, corporate effectiveness and operational performance, leadership and social responsibility).

2. Can be tailored to the characteristics of the business and the field of business.

3. Supports systemic perspective.

4. Based on the diagnosis in accordance with the criteria Excellent and assessment guide.

Excellent MKE is built on mutual values and performance as follows:

1. Leadership that has a vision.

2. Customer-driven benefits.

3. Enterprise and personal learning

4. Awards to employees and partners.

5. Nimble.

6. Focus on the future.

7. Management of innovation.

8. Management based on facts.

9. Responsibility to the community.

10. Focus on value and results

11. Persistence perspective. (Gaol, 2014).

\section{Discussion}

At this writing the author tries to discuss the implementation of HRM and HCM in HR development in Hang Tuah School of Health Science namely:

\subsection{Concept of Human Capital}

In accordance with the theory that Hang Tuah School of Health Science considers employees to be capital possessing knowledge, expertise, and skill on the basis of this, people working at Stik Hang Tuah School of Health Science is can run other resources. Human capital is the accumulation of knowledge, expertise, and other relevant workforce attributes within the organizational strength of an organization and spur the productivity, performance and achievement of strategic objectives.

There has been a change of view on the world environment at this time about various resources that are strategic for the company. The change is from the dominance of physical 
resources (tangible assets) towards intangible assets.

The view that knowledge as a strategic corporate resource is based on the fact that knowledge can be used to develop competitiveness of companies of value, scarce, difficult to imitate by competitors and irreplaceable by other types of resources. So with the existing knowledge of the organization or knowledge through human labor that is in it, then humans are made visible capital (human capital).

Currently Hang Tuah School of Health Science seeks to develop existing employees in order to work well to spur productivity, performance and achievement of strategic goals. In order for Hang Tuah School of Health Science to achieve its strategic objectives then the leadership must develop themselves in accordance with the opinion of Mayo (2000), namely:

a. Individual ability,

b. Individual motivation,

c. Leadership,

d. Organizational mood, and

e. Work group effectiveness.

Human beings as a tangible corporate asset, in addition to building, machinery, and money, are the drivers of resources, whether intangible (machinery, money, material) and intangible (information or data).

In order to compete, competitive advantage as the key of human capital. HR Hang Tuah School of Health Science division is in a prime position to boost many other intangible assets, such as goodwill, research and advertising.

\subsection{Concept of Human Capital Management}

Human Resources Hang Tuah School of Health Science are important in managing existing resources For the purpose of HCM to be realized. The Hang Tuah School of Health Science Human Resources Department must implement the four basic objectives of HCM:

1. Determine the impact of people on the business and their contribution to shareholder value;

2. Demonstrate that human resource practices procedures are worth money, for example, return on investment $(\mathrm{ROI})$;

3. Provide guidance for the future of human resources and business strategies.

4. Provide diagnoses and predictive data that will inform strategies and design practices to improve the effectiveness of people management within the organization.

In order to implement the above objectives required HR manager Hang Tuah School of Health Science has individual capabilities, individual motivation, leadership skills, organizational atmosphere and work group effectiveness in order to motivate employees to work in accordance with the goals set in Hang Tuah School of Health Science.

Dan Kearns (2005a) describes HCM as: 'the development of human potential is totally declared as an organizational value'. He believes that 'HCM is about creating value through 
people' and this is' a philosophy of human development that means something translated into value.

\subsection{Human Capital Management and Human Resource Management}

All managers, especially line managers, should view human resources as one of their important job responsibilities. Unfortunately many managers are not looking at HR or his subordinates as a factor of company performance success. Currently there are still many managers who assume that their subordinates should be used as much as possible or exploited his energy without considering the human aspect.

The Hang Tuah School of Health Science is currently focusing its strategy on creating sustainable competitive advantage, so the focus of the company's human resources is to maximize the contribution of HR to the same goal, creating value for shareholders. The foundation or foundation for a strategy for the creation of human resource values is a management infrastructure that understands and is capable of implementing company strategy.

Unfortunately HR managers at Hang Tuah School of Health Science have limited ability to translate the company's operational strategies and targets into human resources targets that can be followed up, and then implement the targets to be achieved. The ability of these managers to embed human resources into a larger strategy implementation system, which then produces a very important influence for the financial performance of the company. The competencies that HR managers need to develop as well as those that have the greatest impact on company performance are business competencies and strategic HR competencies. However, individual managers must be actively involved.

\subsection{Human Resource Strategy}

The HRM strategy is an approach that defines how organizational goals will be achieved through people by defining human resource strategies and integrated with human resource policies and practices. This is defined by Mabey, et al (1998: 25) as a process of, 'Developing a company's ability to produce new organizational strategies'.

\section{Leadership strategy}

Strategic management can be defined as art and knowledge in formulating, implementing, and evaluating cross-functional decisions that enable an organization to achieve its goals. In essence, a strategic plan is a company's game tactics. Just as a soccer team needs good tactics to win, a company must have a good strategic plan to compete successfully.

In order to achieve its goals Hang Tuah School of Health Science sets the Vision as follows: Vision Hang Tuah School of Health Science is the realization of an institution that excels in the implementation of regional health education in 2036.

To achieve this vision, the leadership strategy is empowerment strategy in internal and external organization and growth strategy by empowering human resources that is:

a. Main Strategy 
1) Establish an accreditation team of accreditation form Hang Tuah School of Health Science because at the end of year 2017 will be reaccreditation of institution which previously accredited with hope will increase become accreditation A.

2) Provide opportunities for faculty staff to continue their S2 and S3 degree education in accordance with their specialization fields by obtaining scholarship from Hang Tuah School of Health Science and also from Higher Education.

3) Providing financial support for lecturers to conduct research and community service in accordance with Tri Dharma Perguruan Tinggi.

4) Establishment of lecture support facilities, currently Hang Tuah School of Health Science has 3 Main Building for lecture hall, Nursing Laboratory, Midwifery, Library and Computer Laboratory Unit that has fulfilled the specifications for CBT exam for graduates of professional doctors, Ners and Midwives profession nationally which has used for competency tests since 2015.

5) The Hang Tuah School of Health Science also pay attention to the needs of his lecturers who are young mothers who in the productive age. To provide a sense of security to mothers of children aged from infants to toddlers, Hang Tuah School of Health Science has provided a nursery room (TPA) for lecturers, so that breastfeeding mothers can breastfeed their babies during feeding hours so that they can succeed in the program Exclusive breastfeeding to children 6 months. This landfill has been running since 2015 .

6) Externally Chairman of Hang Tuah School of Health Science has cooperated with several private and state universities such as; (UGM, University of Riau, STIKES A Yani Cimahi) and also held cooperation with University of Malaysia and Escolar University Manila Philippines.

In April 2017 the Chairman of Hang Tuah School of Health Science and Head of Study Program of Nursing Sciences and Health Science representative A Yani Cimahi has organized a benchmark by visiting Escolar University in Manila, visiting a training center for Overseas Medical Officer, Computer Center (CBT) for professional competence test of Ners and Midwives before being sent abroad. This adds leadership insight to develop Hang Tuah School of Health Science in preparing the quality of graduates who can compete in the market of ASEAN Economic Community (MEA).

\section{b. Competitive Advantage Business Strategy}

At this time Hang Tuah School of Health Science provide educational costs that compete with private education in Riau and provide relief costs for underprivileged students coming from the district / city in Riau and Riau Islands. Currently Hang Tuah School of Health Science provide excellent service / excellent service to prospective new students by providing convenience for regional children to register online and for this year will also be a ball picking system by holding SPMB exam in the district and city.

c. Information Technology Strategy

The Hang Tuah School of Health Science creates an integrated information system called SIAK (Campus Academic Information System) that can be used for filling in KRS (Student 
Registration Card), KHS (Student Learning Result Card), registering new students online and other information.

\section{d. Strategy of Empowerment of Labor}

To empower employees and instill an attitude of employee loyalty to the organization, Hang Tuah School of Health Science leaders have raised the fee for teaching lecturers through senate meetings and conducting training, coaching and mentoring conducted within the institution and also send faculty and staff to attend seminars, workshops and training both within the institution or out of town in accordance with the field of duty. Involve lecturer staff and education personnel in each policy by holding a coordination meeting of all levels by inviting representatives of each course and giving each representative a chance to present useful suggestions and suggestions for the progress and progress of Hang Tuah School of Health Science. Chairman of the Hang Tuah School of Health Science has always been a good listener on every proposal submitted before making a new decision / policy.

\section{e. Working Culture Strategy Effective}

Leaders through the HR Department apply the working hours from 8:00 am to 16:00 hours with working days from Monday to Saturday. Lecturer staff and education personnel should always be in place according to working hours and allowed to exit if there are other tasks such as; guiding students to practice in hospitals, health centers, attending seminars and workshops.

Conducting celebrations of religious holidays by inviting religious teachers and requiring all employees to attend and listen to lectures. In the holy month Ramadhan holds a joint event once a year.

In the implementation of the policy there are several problems, among others, some lecturers have multiple positions, among others, a lecturer concurrently as an eye counselor and also as a lecturer and lecturers of clinical practice students and also must perform community service and research as Tri Dharma Perguruan Tinggi. This can happen because there are still many lecturers who continue S2 education and there are S3. Lecturer workload more than 12 - 16 credits, some up to 24 credits. This can cause burnout / burnout.

\section{f. Leadership Ethics}

Leadership ethics is implemented by instilling values of trust, honesty, loyalty, togetherness, mutual respect and respect for the elderly. Ethics is a sign of moral principles and values that govern the behavior of every person or society by respecting what is considered wrong and true. Ethics is not the same as law.

\section{g. Leadership style}

Mr. Chair's leadership style is more Y-oriented transformational Leadership, which views employees as responsible, has an inner awareness to work, and is proud of his work, and Communicative, persuasive and participative leadership style. The Chairperson gives flexibility to the study program leaders to develop their respective projects and to give confidence to the staff to run the policies in accordance with the vision, mission of the 
organization in a flexible and controlled.

h. Strategies for Leading Change

To carry out every change Chairman of the Hang Tuah School of Health Science always do it gradually and is persuasive. Any changes before the implementation is always held in advance by inviting representatives of each study program and to get input and review the advantages and disadvantages of any changes that will be made. Before the policy is established, a 3 month trial is firstly conducted by monitoring its progress and seeing the impact of the changes. This can minimize resistance to change. The Chairman appoints people who are trustworthy and deemed capable of supporting change.

\section{Human Resources Manager}

In order for the strategies and policies established by the Hang Tuah School of Health Science leadership to be properly implemented, the HR Manager is obliged to implement them by preparing written rules on Standard Operating Procedures (SOP) of each activity, SOP example; Acceptance of Lecturers, Entrance, Letter of Exit, Reception of Personnel, Election of Chairman and Secretary, Service of Cooperation with Outside, Monitoring of Employee Performance Evaluation, Further Study, Employee Ethics, etc.

The following examples of standard operating procedures Cooperation Services with outsiders

Table 2. The Standard Operating Procedure Cooperative Services

\begin{tabular}{|c|c|c|}
\hline & \multicolumn{2}{|c|}{$\begin{array}{l}\text { OPERATIONAL PROCEDURES STANDARDS OF NURSING } \\
\text { EDUCATION } \\
\text { COOPERATION SERVICES WITH OUTSIDE PARTIES }\end{array}$} \\
\hline & $\begin{array}{l}\text { Document No. } \\
\text { B } 009\end{array}$ & \begin{tabular}{|c|c} 
Revision No. & Page \\
00 & 2
\end{tabular} \\
\hline PROCEDURES & $\begin{array}{l}\text { Published Date: December } \\
13,2010\end{array}$ & $\begin{array}{c}\text { Determined by: } \\
\text { Study program of the Hang Tuah School of } \\
\text { Health Science }\end{array}$ \\
\hline UNDERSTANDING & \multicolumn{2}{|c|}{$\begin{array}{l}\text { Cooperation service is cooperation with other institution / party outside study } \\
\text { program of the Hang Tuah School of Health Science which is legal. }\end{array}$} \\
\hline PURPOSE & \multicolumn{2}{|c|}{$\begin{array}{l}\text { This procedural operating standard (SOP) aims to provide an explanation of } \\
\text { a. Procedures implementation of cooperation between PSIK with other } \\
\text { institutions } \\
\text { b. Procedures for determining personnel involved in cooperation with the } \\
\text { agency / party }\end{array}$} \\
\hline SCOPE & \multicolumn{2}{|c|}{$\begin{array}{l}\text { This procedure applies to RSUD, RSJ, Public Health Service, Public Health } \\
\text { Center, Panti Werda and others }\end{array}$} \\
\hline PROCEDURE & \multicolumn{2}{|c|}{$\begin{array}{l}\text { 1. Any plan of cooperation made with outsiders shall be made to the } \\
\text { Chairman of PSIK Prodi and approved by the chairman of the Hang } \\
\text { Tuah School of Health Science } \\
\text { 2. Working procedures include Tri Darma Perguruan Tinggi } \\
\text { 3. Any cooperation done with outsiders shall have documented outcome of } \\
\text { the cooperation that has been done to be archived } \\
\text { 4. Cooperation that has financial value, should be notified to the chairman } \\
\text { the Hang Tuah School of Health Science about the amount of funds used } \\
\text { 5. Fighting cooperation in accordance with the time that has been agreed } \\
\text { upon }\end{array}$} \\
\hline PERSON IN CHARGE & \multicolumn{2}{|c|}{ Head of Study Program PSIK Hang Tuah Pekanbaru and secretary } \\
\hline RELATED DOCUMENT & \multicolumn{2}{|c|}{$\begin{array}{l}\text { Internal quality assurance center and research institute and community } \\
\text { service }\end{array}$} \\
\hline
\end{tabular}




\section{Macrothink}

International Journal of Human Resource Studies

ISSN 2162-3058

2018, Vol. 8, No. 1

With the SOP of each activity, it will facilitate the Human Resource Manager in monitoring and evaluating each activity whether it has been implemented properly and correctly or implemented not in accordance with the SOP, so that the Human Resource Manager can recommend to the leadership to give awards to employees who excel or either written warning or verbal reprimands to employees whose performance does not comply with STIKES policy.

But at this time according to the author HR Manager cannot fully implement the policies that have been outlined by the leadership. The HR manager has not been able to fully motivate employees to work in accordance with SOPs, for example; Human resource managers are still unable to discipline employees to smoke at the campus area even though there are regulations on smoking ban on campus area, making correspondence in the form of SK about lecturers 'departments are often late, SK about late lecturers' study permit, SK about appointment of new employees too late. Difficulty communicating with HR managers, often not in place, often requesting back reports from each of the previously awarded study programs.

a. Response

1. As Chairman has a clear vision and mission that is presented to employees as human resources / human capital that is important for the implementation of the vision and mission of the organization. In accordance with opinion Chatzkel (2004) states that: 'Human Capital Management is an integrated effort to manage and develop human capabilities to achieve significantly higher levels of performance'.

Dan Kearns (2005a) describes HCM as: 'the development of human potential is totally declared as an organizational value'. He believes that 'HCM is about creating value through people' and this is 'a philosophy of human development that means something translated into value'.

This is according to the author in line with Eleven Core Values in Performance Management excellent, where MKE is built based on the values and performance are interrelated as follows:

a. Leadership that has a vision.

b. Customer-driven benefits.

c. Corporate and personal learning

d. Award to employees and partners.

e. Agility.

f. Focus on the future.

g. Management of innovation.

h. Management based on facts.

i. Responsibility to society.

j. Focus on value and results.

k. Persistence perspective.

b. Human Resource Manager cannot fully support the implementation of policies that have 
been set by the leadership.

Still lack of understanding of Human Resources Manager on Human Capital investment. As according to the theory of the current Human Resource Function: which includes the Functions:

a. The structure that is, who reports to whom, role, and accountability,

b. System (i.e., performance measures, business reviews),

c. Shared values (i.e., beliefs, cultural values),

d. Skills / skills (i.e., talent, knowledge). The elements are parallel to each other.

\section{Conclusion}

From the description above the author can conclude the implementation of Human Capital Management in Hang Tuah School of Health Science namely:

1. Chairman of the Hang Tuah School of Health Science has a clear vision and mission in implementing Human Capital Management.

2. The Chair sets out strategies for empowerment in internal and external organizations and growth strategies by empowering human resources.

3. Still lack of understanding of Human Capital Manager about Human Capital as an organizational asset.

\section{Recommendations}

1. According to the authors need reinforcement on the HR of the Hang Tuah School of Health Science, so that all strategies and policies that have been set by the leadership can be done properly and correctly. In order for the HR Section to apply the Working Model of excellent by integrating the managerial process and business results achieved. Which cover; leadership, Strategic Planning, customer and market focus, process management and business results. To help organizations improve their performance, both process performance and yield performance.

2. Need to understand and change the paradigm of the HR Manager that more and more companies are interested in using invisible assets and human capital as a way to gain more profit from competitors.

\section{Reference}

Armstrong, M. (2012). Armstrong's Handbook of Human Resource Management Practice. Ed-12. London: Kogan Page.

Baron, A., \& Armstrong, M. (2007). Human Capital Management Achieving Added Value through People. London and Philadelphia: Kogan Page.

David, F. R. (2012). Manajemen Strategis Konsep. Ed-12, Buku 1. Terj. Dono Sunardi. Jakarta: Salemba Empat.

Dessler, G. (2016). Fundamentals of Human Resource Management. Ed-4. England: Pearson Education. 


\section{Macrothink}

International Journal of Human Resource Studies

ISSN 2162-3058 2018, Vol. 8, No. 1

Gaol, C. H. R., \& Human, J. L. (2014). Capital Manjemen Sumber Daya Manusia. Jakarta: Grasindo.

Hall, B. W. (2008). The New Human Capital Strategy Improving the value of your most important investment year after year. New York: Amacom.

Mayo, A. (2012). Human Resource or Human Capital? Managing People as Assets. London: Routledge Publication.

STIKES Hang Tuah. (2010). Dokumen Standar Operasional prosedur Program Studi Ilmu Keperawatan STIKES Hang Tuah Pekanbaru. Pekanbaru.

Sutrisno, E. (2016). Manajemen Sumber Daya Manusia. Ed-1. Cet-8. Jakarta: Prenadamedia Group.

\section{Copyright Disclaimer}

Copyright for this article is retained by the author(s), with first publication rights granted to the journal.

This is an open-access article distributed under the terms and conditions of the Creative Commons Attribution license (http://creativecommons.org/licenses/by/4.0/). 